\title{
MASIER
}

\section{Impact Analysis of Spent Nuclear Fuel Shipping Casks}

Micheal Huerta, Albert W. Dennis, Richard H. Yoshimura

Prepared by Sandia Laboratories, Albuquerque, New Mexico 87185 and Livermore, California 94550 for the United States Department of Energy under Contract AT(29-1)-789

Printed July 1978 


\section{DISCLAIMER}

This report was prepared as an account of work sponsored by an agency of the United States Government. Neither the United States Government nor any agency Thereof, nor any of their employees, makes any warranty, express or implied, or assumes any legal liability or responsibility for the accuracy, completeness, or usefulness of any information, apparatus, product, or process disclosed, or represents that its use would not infringe privately owned rights. Reference herein to any specific commercial product, process, or service by trade name, trademark, manufacturer, or otherwise does not necessarily constitute or imply its endorsement, recommendation, or favoring by the United States Government or any agency thereof. The views and opinions of authors expressed herein do not necessarily state or reflect those of the United States Government or any agency thereof. 


\section{DISCLAIMER}

Portions of this document may be illegible in electronic image products. Images are produced from the best available original document. 
Issued by Sandia Laboratories, operated for the United States Department of Energy by Sandia Corporation.

\section{NOTICE}

This report was prepared as an account of work sponsored by the United States Government. Neither the United States nor the United States Department of Energy, nor any of their employees, nor any of their contractors, subcontractors, or their employees, makes any warranty, express or implied, or assumes any legal liability or responsibility for the accuracy, completeness or usefulness of any information, apparatus, product or process disclosed, or represents that its use would not infringe privately owned rights.

Printed in the United States of America

Available from

National Technical Information Service

U. S. Department of Commerce

5285 Port Royal Road

Springfield, VA 22161

Price: Printed Copy $\$ 4.00$; Microfiche $\$ 3.00$ 


\section{PAGES 1 to 2 WERE INTENTIONALLY LEFT BLANK}


Richard H. Yoshimura Transportation Safety Technology Division 5433

Sandia Laboratories Albuquerque, NM 87185

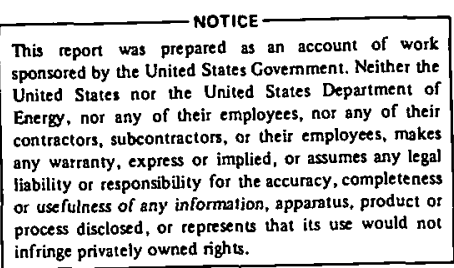

This report was prepared as an account of work sponsored by the United States Government. Neither the Enited States nor the United States Depany of their contractors, subcontractors, of their employees, makes any wartanty, express or inglied, or ascy, completeness or usefulness of any information, apparatus, product no infringe privately owned rights.

\section{A RSTRAAT}

This paper summarizes a presentation made at the CÜBE (Computer Use By Engineers) Symposium, October 1976, in Albuquerque, New Mexico. A fullscale testing program involving impact tests of spent-nuclear-fuel shipping systems is described. This program is being conducted by Sandia Laboratories for the Environmental Control Technology Division of the U.S. Energy Research and Development Administration. The paper describes the analytical and scale modeling teehniques being employed to predict the rcaponoc of the full-scale system in the very severe impact tests. 'The analytical techniques include lumped parameter modeling of the vehicle and cask system and finite modeling of isolated shipping casks. Some preliminary results from the mathematical analyses and scale model tests demonstrate close agreement between these two techniques. Scale models of the systems are also described and some results presented.

* This work was supported by the United States Energy Research and Development Administration. 
CONTENTS

Page

Introduction

Full Scale Tests

Test Number 1

Test Number 2

Test Number 3

Scale Model Analysis

Truck-Trailer Model

Locomotive Model

Railcar Model

Analytical Models

Lumped-Parameter Models

Finite Element Models

Conclusion

References 


\section{ILLUSTRATIONS}

\section{Figure}

1 Schematic Illustration of the Truck-Trailer Test

8

Schematic Illustration of the Grade Crossing Test

Schematic Illustration of the Derailment Test

Photograph of the Model Truck-Trailer System at the Sled Track Facility

Shock Model of the Truck-Trailer System

Displacement-Time History for the Truck Cask After Impact

Deformed Mesh for the Cask Calculated with HONDO 
Introduction

Sandia Laboratories will be conducting a series of full-scale crash tests involving leadshielded spent nuclear fuel shipping systems. ERDA and Sandia devised these tests to simulate extremely severe accident conditions involving both rail and highway carriers of hazardous material packaging systems.

Before conducting the tests, Sandia engineers are performing a number of analyses to predict the response of the systems. These analyses stress two areas of interest: analyses of isolated casks impacting unyielding surfaces, and analyses of the transportation system and cask. In the first instance, the tests give insight into the generic behavior of lead shielded casks. In the second, the tests help predict the behavior of the complete system when it is subjected to the more realistic accident conditions of the proposed full-scale tests.

This report, which summarizes the Computer Use By Engineers (CUBE) Symposium presentation, describes the full-scale tests and some of the analyses relating to them. Preliminary results of analytical studies using a lumped parameter code to model the cask and transportation system are presented and related to results of scale model tests. A technique of modeling cask side-impacts using a dynamic finite element code is discussed, and some results using this technique are presented and correlated to results of scale model tests.

Full Scale Tests*

The full-scale test program calls for three vehicle crashes involving out-of-service truck and rail spent fuel shipping casks. Economic reasons dictate the use of out-of-service systems dating back to the 1960's; structurally they are similar to present day units. The tests will be instrumented to measure the response of actual hardware under simulated accident conditions. The tests are: (1) tractor-trailer crash into a solid concrete barrier while carrying a spent fuel shipping cask, (2) high speed locomotive grade crossing impact with a tractor-trailer carrying a large spent fuel shipping cask, and (3) high speed collision and fire involving a special railcar carrying a spent fuel shipping cask.

*The tests have conducted since the CUBE Symposium. Other reports describing the results of the tests have been published. 


\section{Test Number 1}

The first test will be the head-on collision at a nominal $97 \mathrm{~km} / \mathrm{hr}(60 \mathrm{mph})$ of a tractortrailer with a spent fuel cask into an immovable barrier, which represents a massive concrete bridge abutment or retaining wall. The lead-shielded cask weighs $20,500 \mathrm{~kg}$. A cluster of rocket motors will accelerate the transport system to test velocity. The truck transport will straddle a section of a standard railroad track; a trolley system connecting the tractor frame to the rails will guide the truck. Figure 1 is a schematic of the test arrangement. The reinforced concrete target, which has a mass of $6.3 \times 10^{5} \mathrm{~kg}$ and is backed with a large amount of earth, is located in the Sandia Laboratories Environmental Test Area.

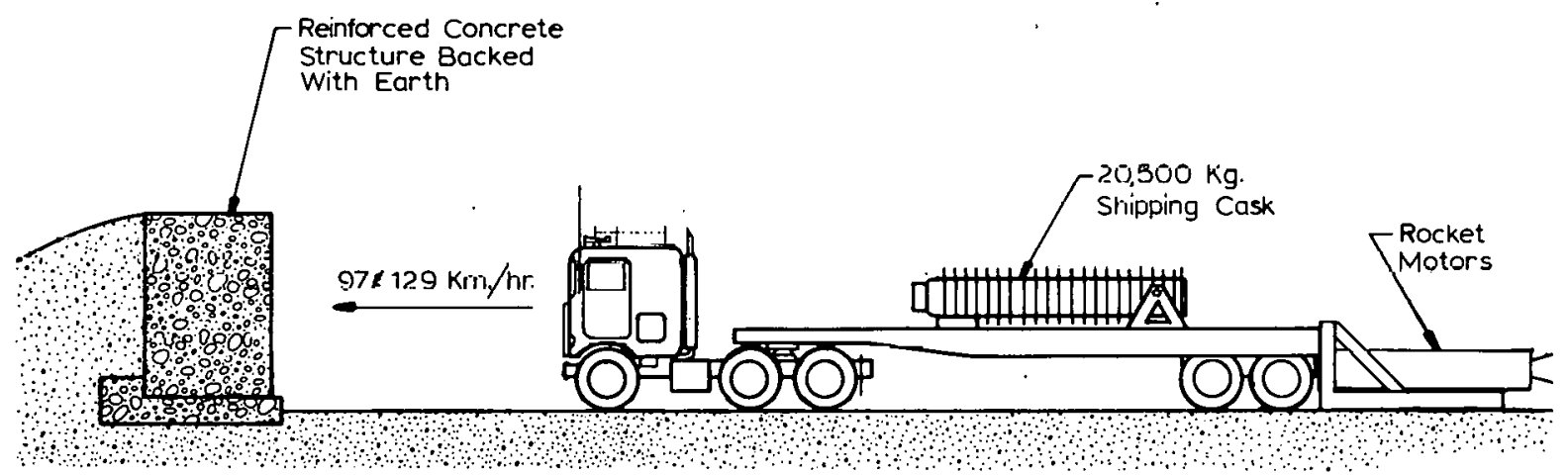

Figure 1. Schematic Illustration of the Truck-Trailer Test

\section{Test Number 2}

The second full-scale test will involve the broadside impact of a locomotive, traveling at high speed, into a truck-mounted spent fuel cask positioned on a simulated grade crossing. The locomotive will impact the cask and trailer at a speed of between 113 and $129 \mathrm{~km} / \mathrm{hr}$. Figure 2 is a schematic of the test arrangement. The locomotive is a 109 -metric ton surplus military unit. It will impact a $24,000 \mathrm{~kg}$ lead-shielded cask mounted on the truck.

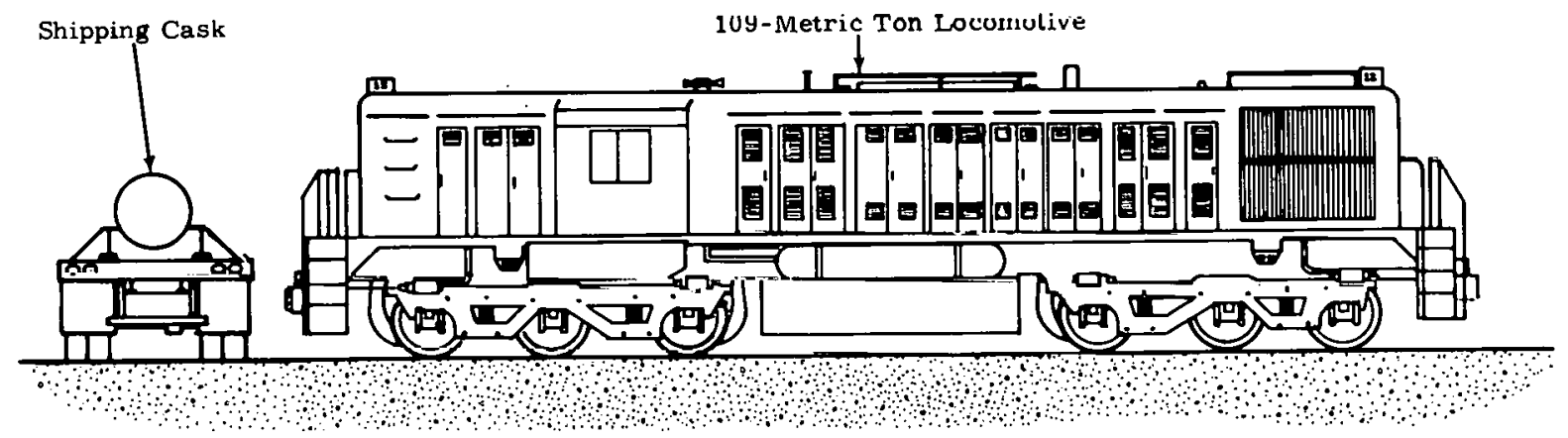

Figure 2. Schematic Illustration of the Grade Crossing 'l est 


\section{Test Number 3}

The third test will subject a special railcar and spent fuel cask to a simulated derailment and impact into a massive concrete abutment at high speed. The railcar will be guided on a section of rail leading to the target. Figure 3 illustrates the test configuration.

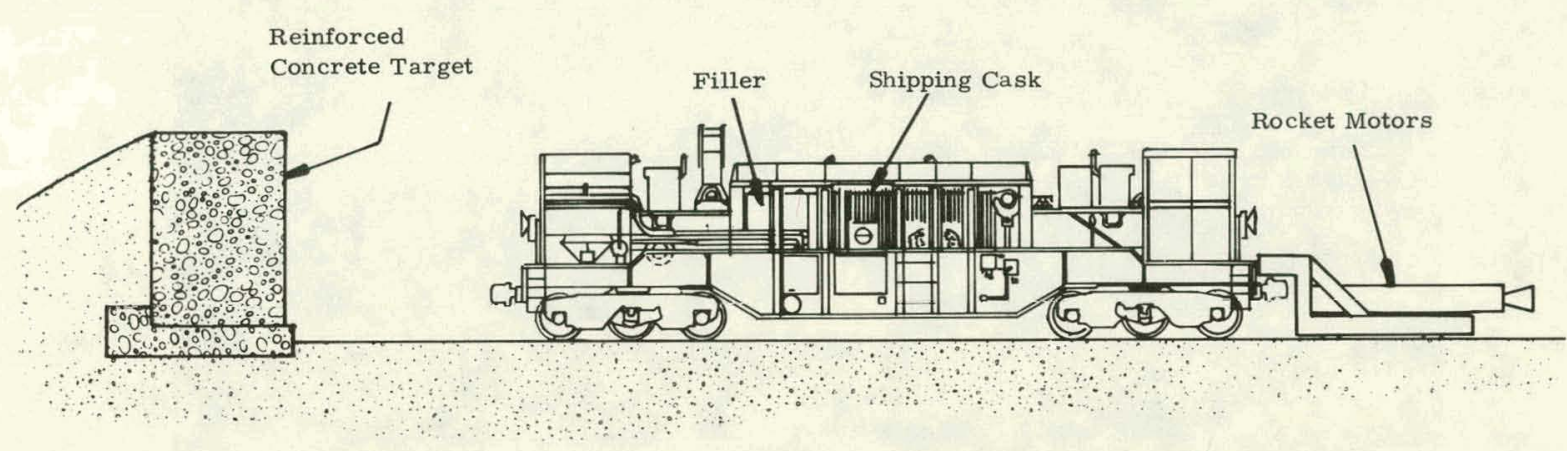

Figure 3. Schematic Illustration of the Derailment Test

The special railcar system consists of a $6.8 \times 10^{4} \mathrm{~kg}$ car carrying a $68,000 \mathrm{~kg}$ spent-fuel rail cask. The cask is carried inside a structural steel cage that is an integral part of the railcar frame. Rocket motors will propel this system.

Scale Model Analysis

A series of rocket sled track tests using 1/8-scale models plays a prominent part in modeling the dynamics and the cask damage to be encountered in the full-scale tests just described. The models, running on a single rail, are accelerated by a pusher sled to a velocity slightly greater than the intended impact velocity and allowed to coast into the target and impact at the desired velocity. Models, which were constructed for each of the full scale tests, are described below.

$\underline{\text { Truck-Trailer Model }}$

Figure 4 is a photograph of the truck-trailer system about to impact the model target. The system, which includes a model tractor, trailer, cask, and tiedowns, has a mass of approximately $59 \mathrm{~kg}$. The cask was carefully designed to adequately duplicate the prototype. 'The tractor and trailer model structures were designed to simulate the deformation behavior and energy absorption of the prototype units. 


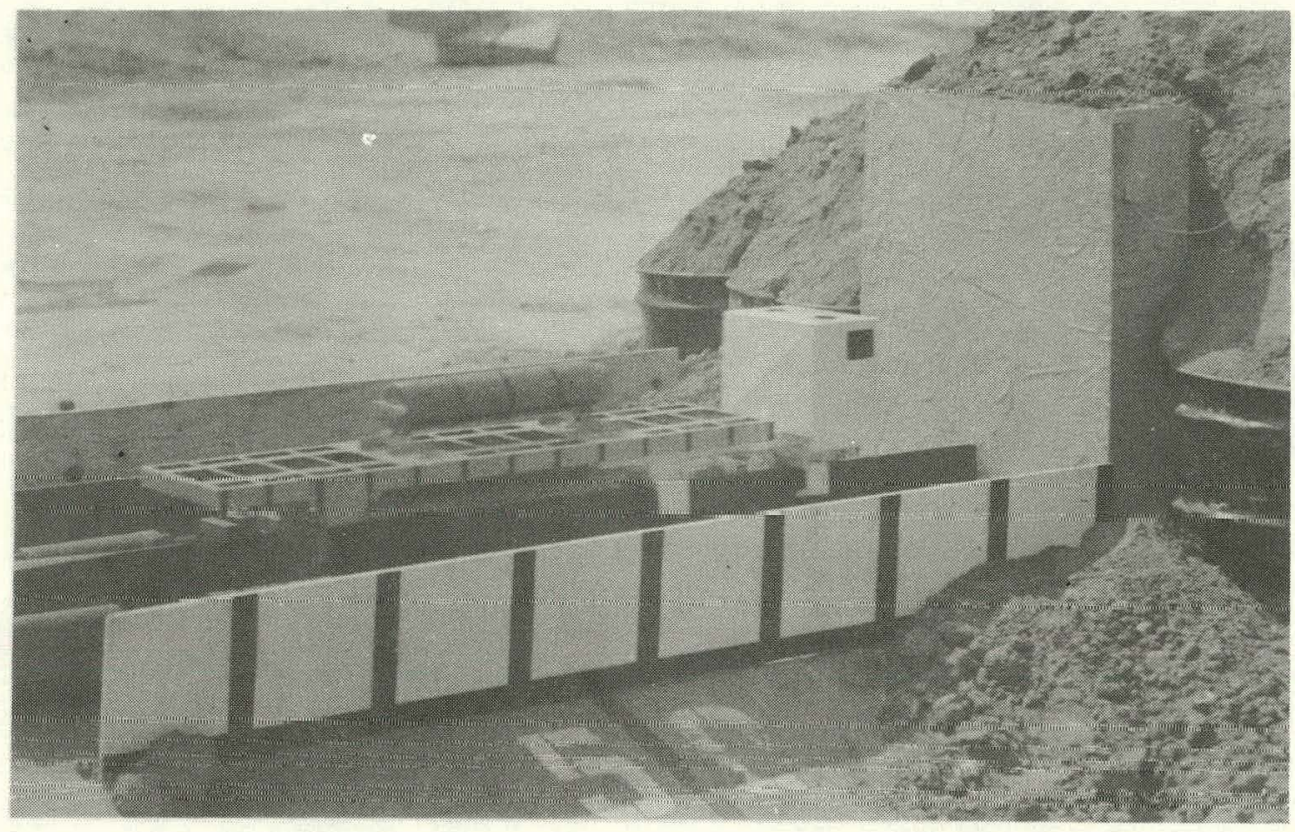

Figure 4. Photograph of the Model Truck-Trailer System at the Sler Trark Farility

\section{Locomotive Model}

The grade-crossing test of a locomotive impacting a stationary cask is also being analyzed with scale models. Figure 5 illustrates this model. The model locomotive includes structures that simulate the engine and alternator, constituting the main parts of the superstructure. The locomotive underframe was also modeled. Tests were run with the cask placed at different elevations.

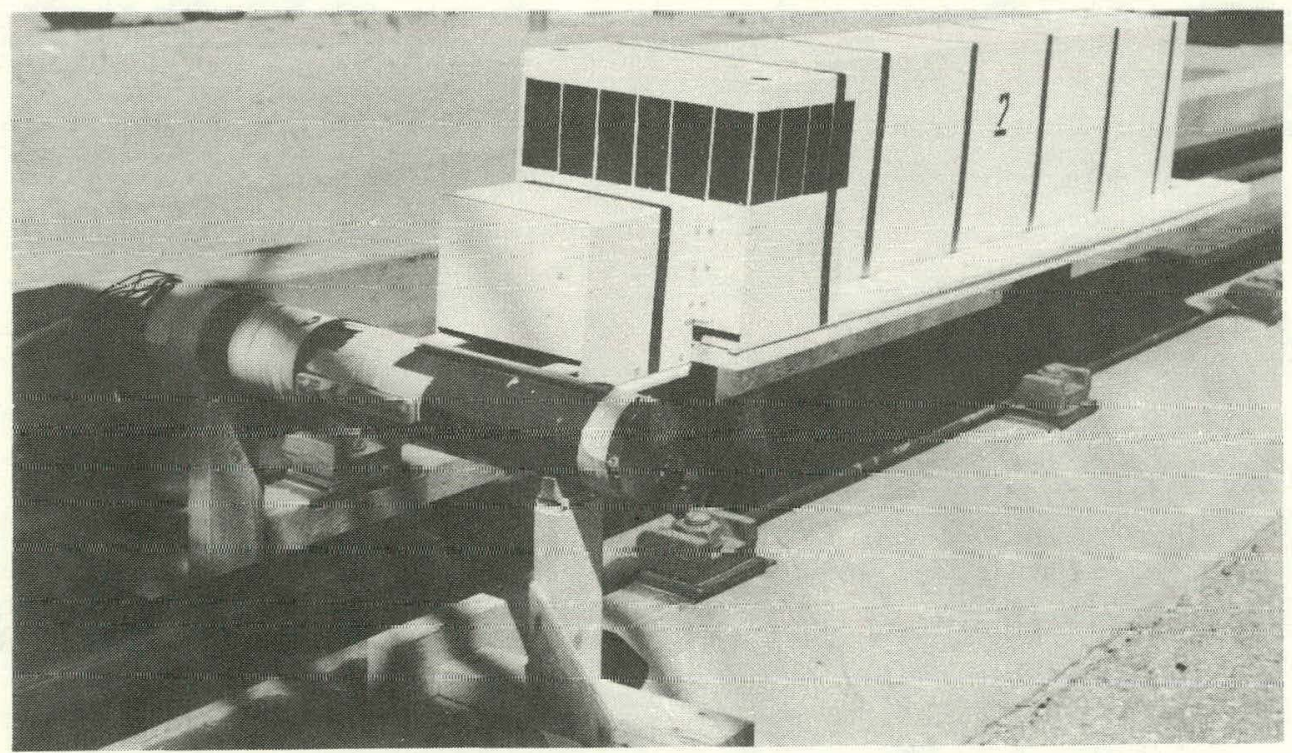

Figure 5. Photograph of Model Locomotive and Cask at the Sled Track Facility 


\section{Railcar Model}

Figure 6 illustrates the scale model railcar and cask. Each principal member of the prototype structure, as well as the cask, were modeled and several of these units were built. Experiments are being conducted to determine the response of the full-scale systems.

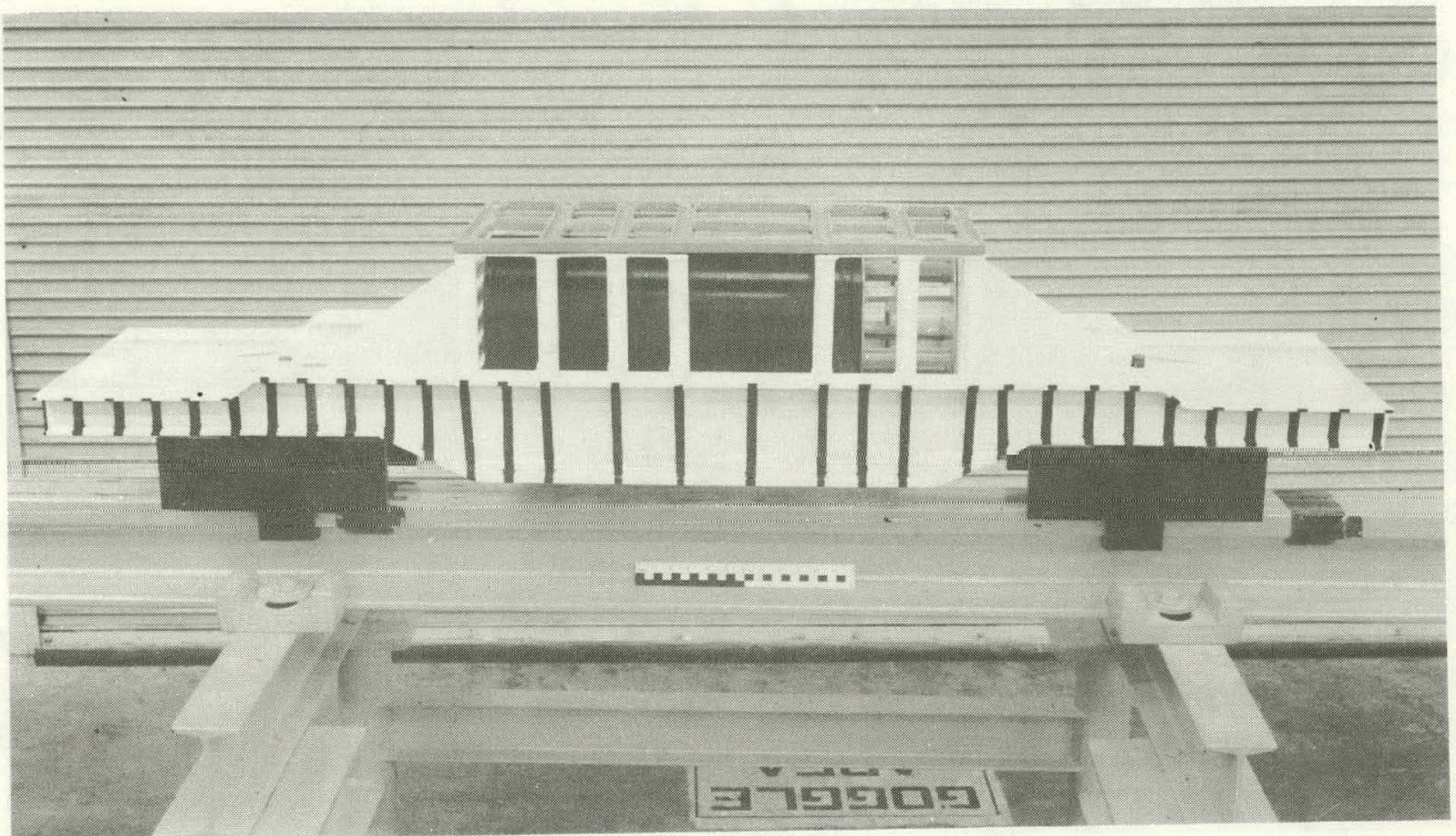

Figure 6. Photograph of the Model Railcar

\section{Analytical Models}

The full-scale tests are being analyzed by means of computer models. This includes work with a lumped-parameter computer program and dynamic finite element modeling.

\section{Lumped Parameter Models}

The response of the overall system in each case is analyzed by means of SHOCK ${ }^{1}$, a onedimensional lumped parameter computer program. In this program the system is represented by discrete masses and couplings. The coupling definitions are based on analytical estimates of the load-displacement behavior of the structure. Large permanent deformations are approximated by hysteresis-type couplings. These are piecewise linear couplings with provisions for different loading and unloading paths. 
Figure 7 illustrates a loading curve for hysteresis Type I coupling. This type of coupling can be used either in compression or in tension. Up to six loading segments may be defined. A Type IV hysteresis coupling, which has provisions for both compression and tension loading, is also being used. The Type IV coupling is limited to two straight-line segments. In addition to a hysteresis coupling, linear springs are used.

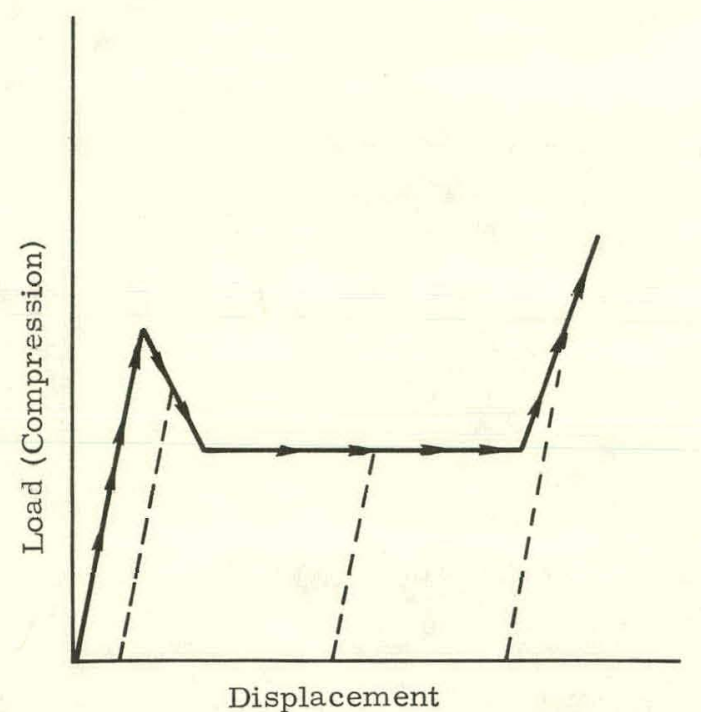

Figure 7. Loading Curve for a Hysteresis Type I Coupling

Analytical models for the three full-scale tests were constructed using the SHOCK Program. Figure 8 illustrates the model for the tractor-trailer impact. Here the system, including the target was modeled with eight discrete masses and ten couplings. Mass 1, the target, is held fixed and the remaining masses are given initial velocities equal to the test-impact velocity. In this model, coupling 3-4 represents the tractor-trailer kingpin connection and couplings 5-6 and 6-7 simulate the cask tiedowns. Couplings 1-4 and 1-6 represent the interactions between the end of the trailer and the target and the cask and the target. 'I'hese are given appropriate amounts of travel without loading. The rest of the couplings represent frame elements. Preliminary results obtained with this model are presented in this paper.

'The railcar impact was modeled using the lumped-parameter technique and subsequcntly refined. Figure 9 illustrates the model for this system. Here masses 2-12 represent the railcar frame, mass 13 represents the filler unit, and masses 14-17 represent the cask. Runs were made with both of these truck and railcar models, and results were compared with scale model tests. 


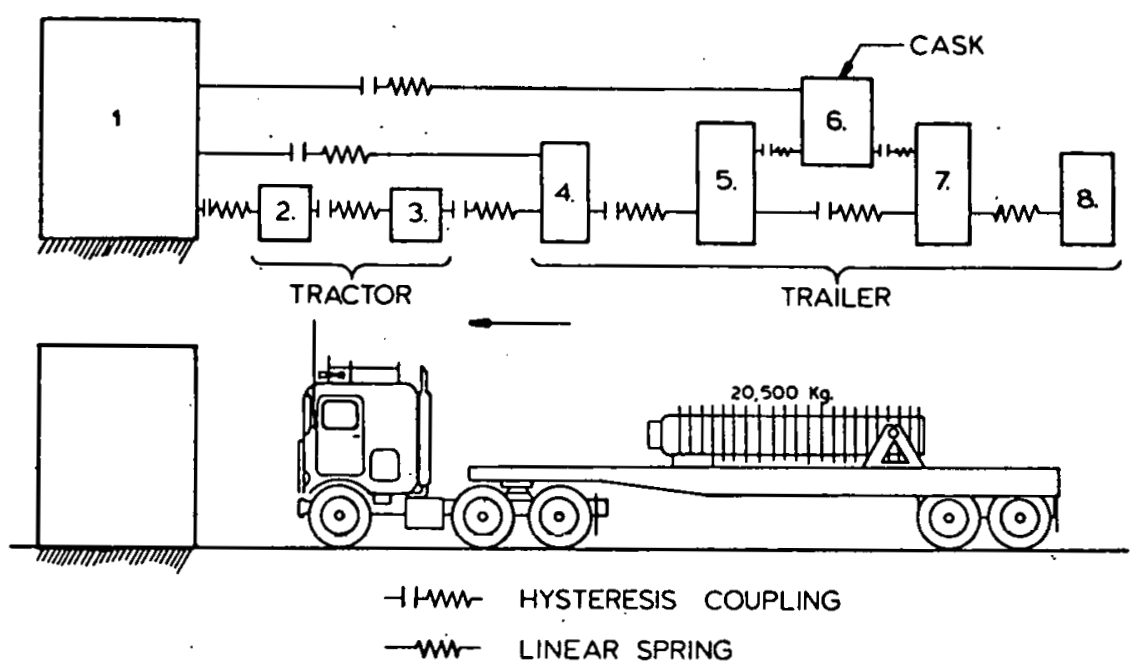

Figure 8. Shock Model of the Truck-Trailer System
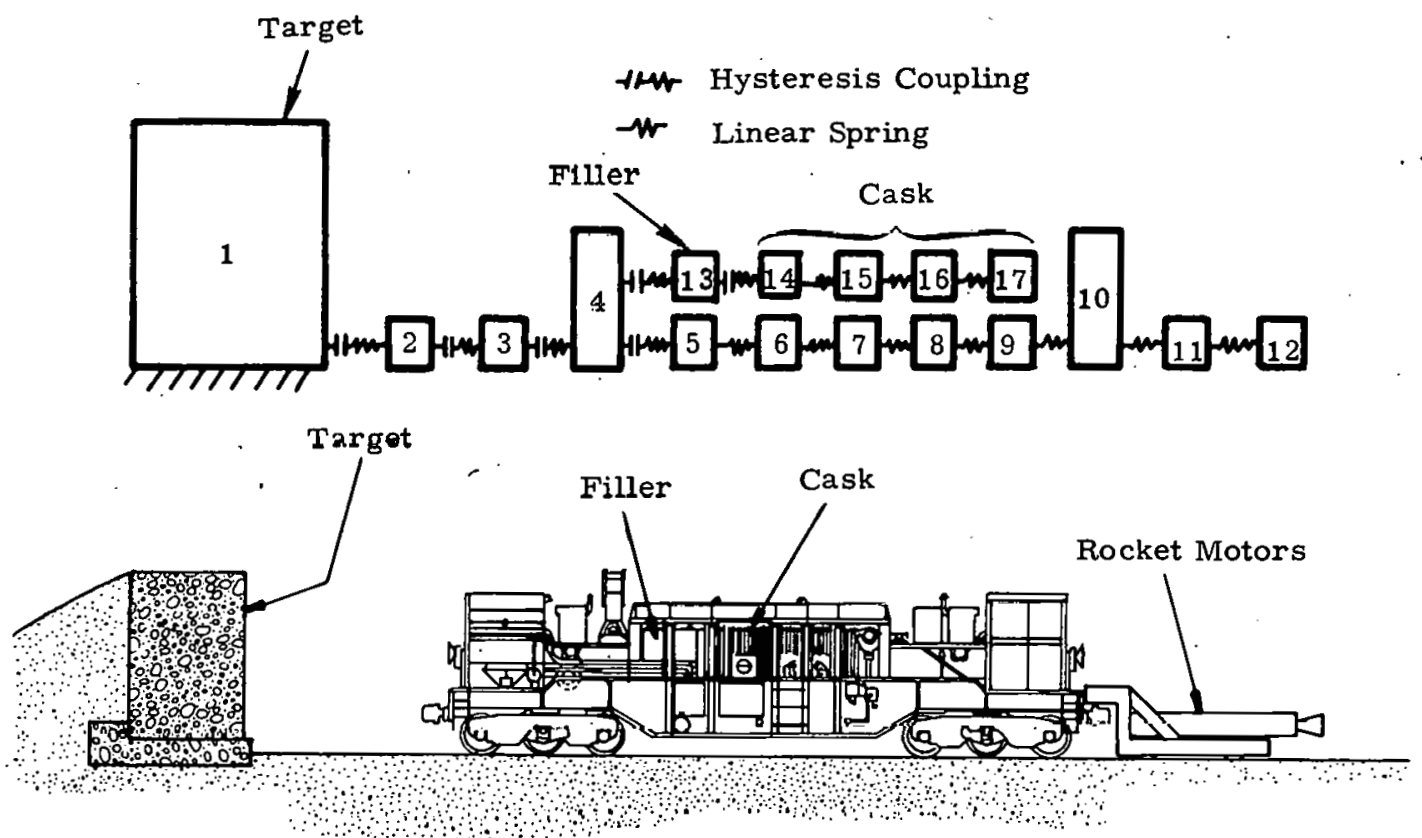

Figure $\theta$. Shock Model of the Railcar System 
Figure 10 illustrates a displacement time history $(129 \mathrm{~km} / \mathrm{hr}$ impact velocity) for the truck cask calculated from the SHOCK model. Data from films of a scale model test are superimposed on these results. As can be seen, the two agree reasonably well. The late time difference indicates that the couplings which connect the front end of the trailer to the target and the cask to the target need some further calibration. This model will undergo some minor refinement prior to the full-scale test.

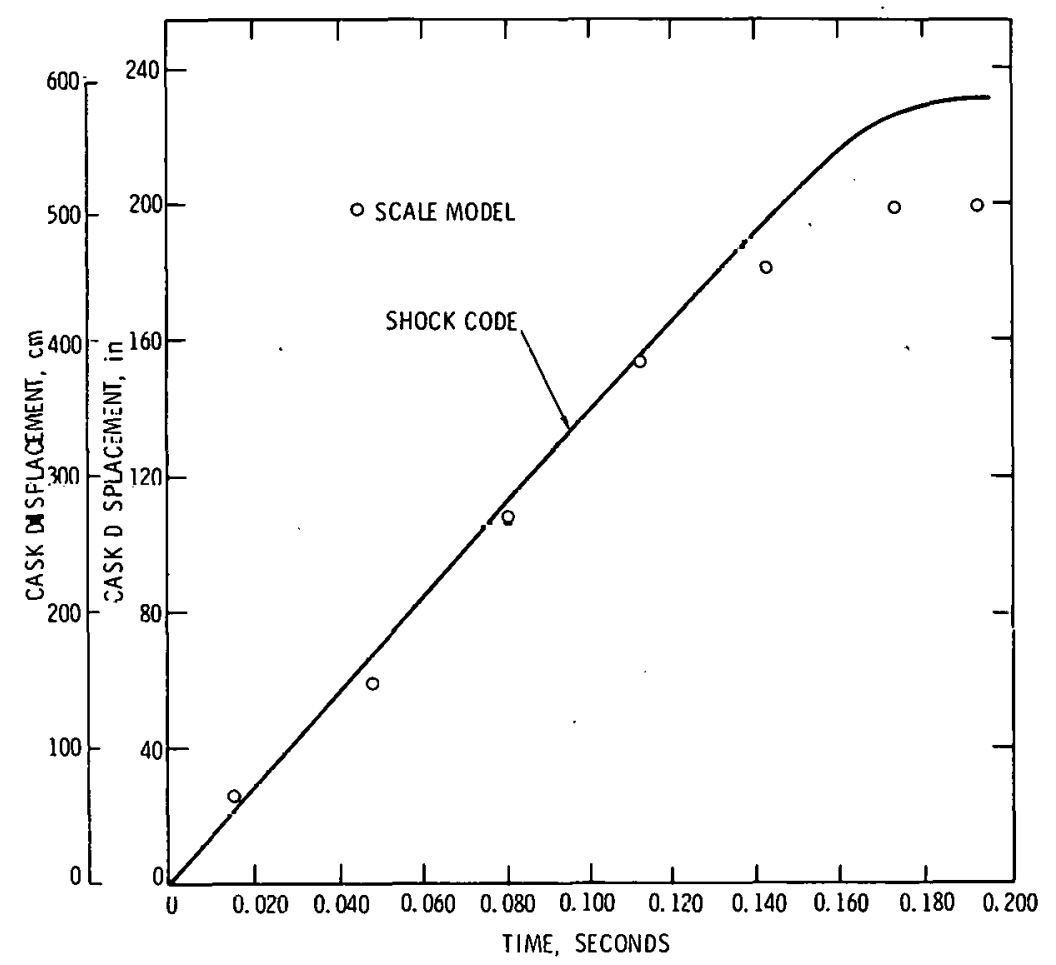

Figure 10. Displacement-Time History for the Truck Cask After Impact (129 $\mathrm{Km} / \mathrm{hr}$ impact velocity)

Figure 11 illustrates velocity-time results for the cask when the system is involved in a $97-$ $\mathrm{km} / \mathrm{hr}$ impact. These data were obtained with the truck lumped parameter model. Two cases representing extreme conditions are illustrated. In the worst condition, the kingpin connection and the cask tiedown were assumed to be weak and failure of these connections occurred early. The result was a very severe impact of the cask into the concrete. In the more favorable condition, these couplings were given values which were high but still reasonable. 'I'his condition should result in much more kinetic energy absorption by the tractor and trailer structure and a lower impact velocity of the cask onto the concrete. The two cases are expected to bound the real condition. 


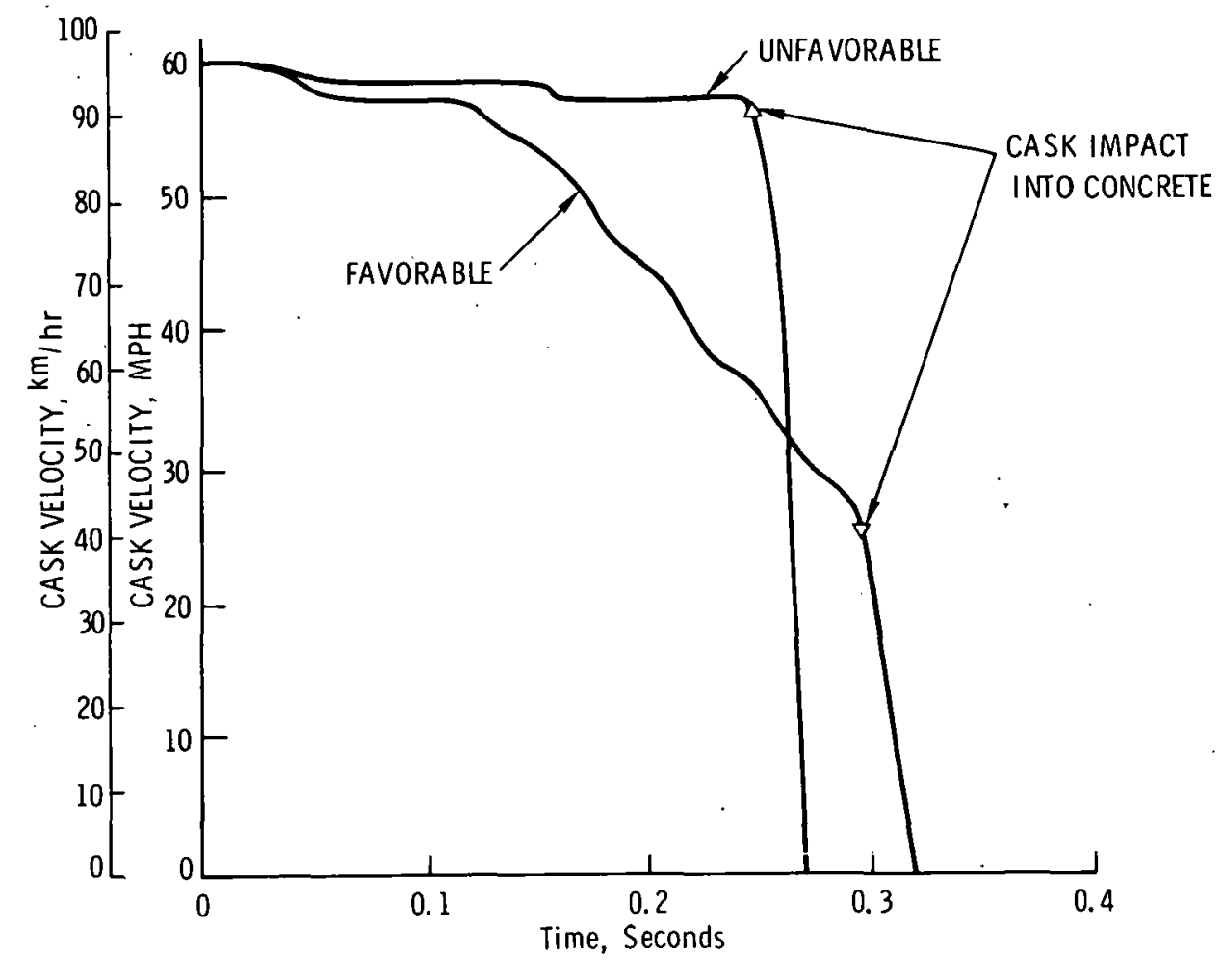

Figure 11. Velocity-Time History for the Truck Cask After Impact

Figure 12 illustrates displacement-time results from the SHOCK code model for the railcar; and data from the scale model tests are superimposed. The SHOCK model of the railcar appears to be stiffer than the scale model, allowing less lateral cask movement. Agreement, however, is still reasonably good. Additional refinements will be made to the model prior to the full-scale test.

Figure 13 illustrates the velocity-time history for the cask calculated with the lumped parameter model. The curve shows that the cask decelerates very uniformly within the cage structure. This agrees with what has been observed in scale model test films. This same technique, using the SHOCK code, was used to model the grade crossing tests in which the locomotive impacts a large stationary cask. ${ }^{2}$ 


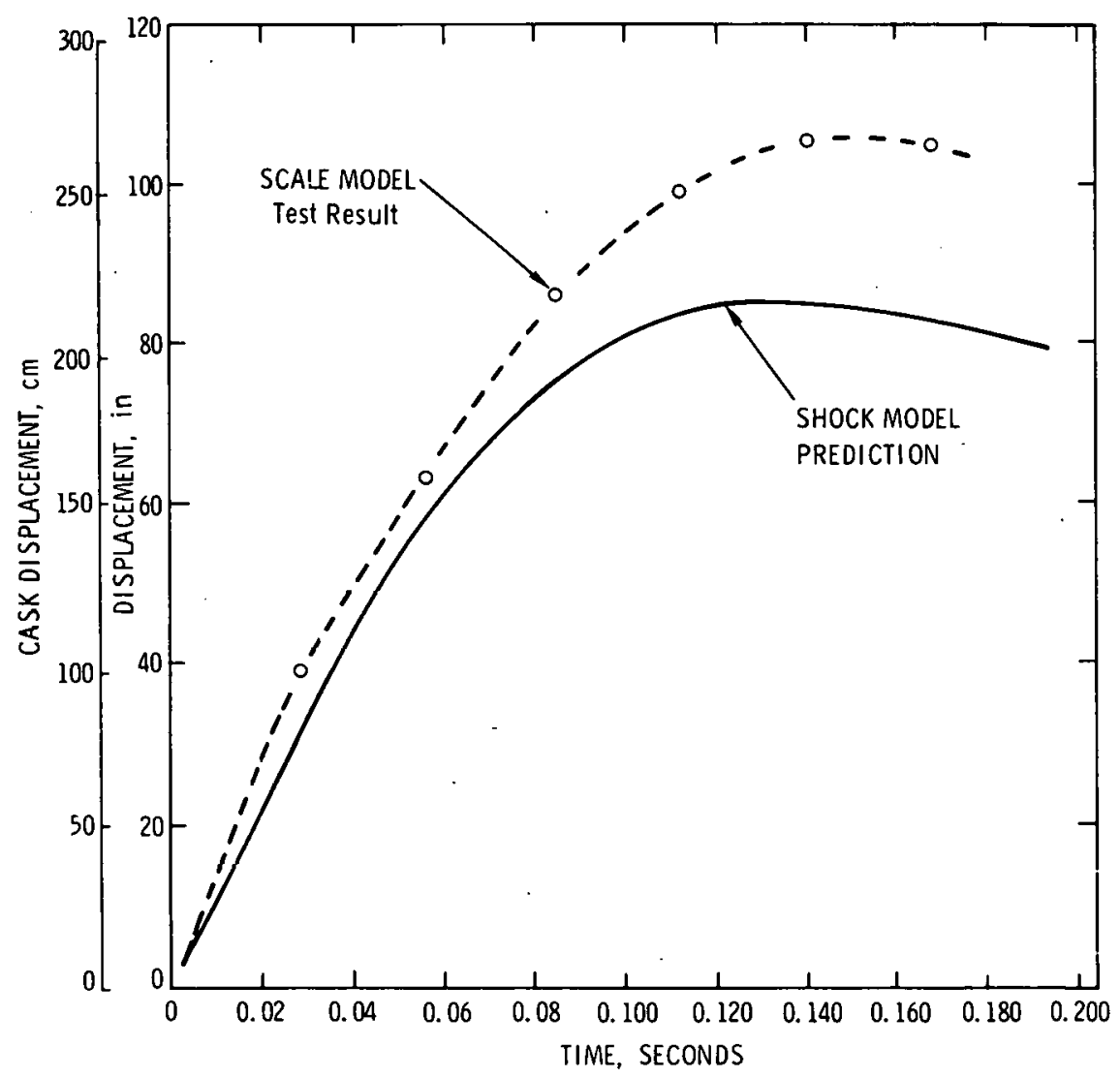

Figure 12. Displacement-Time History for the Rail Cask After Impact

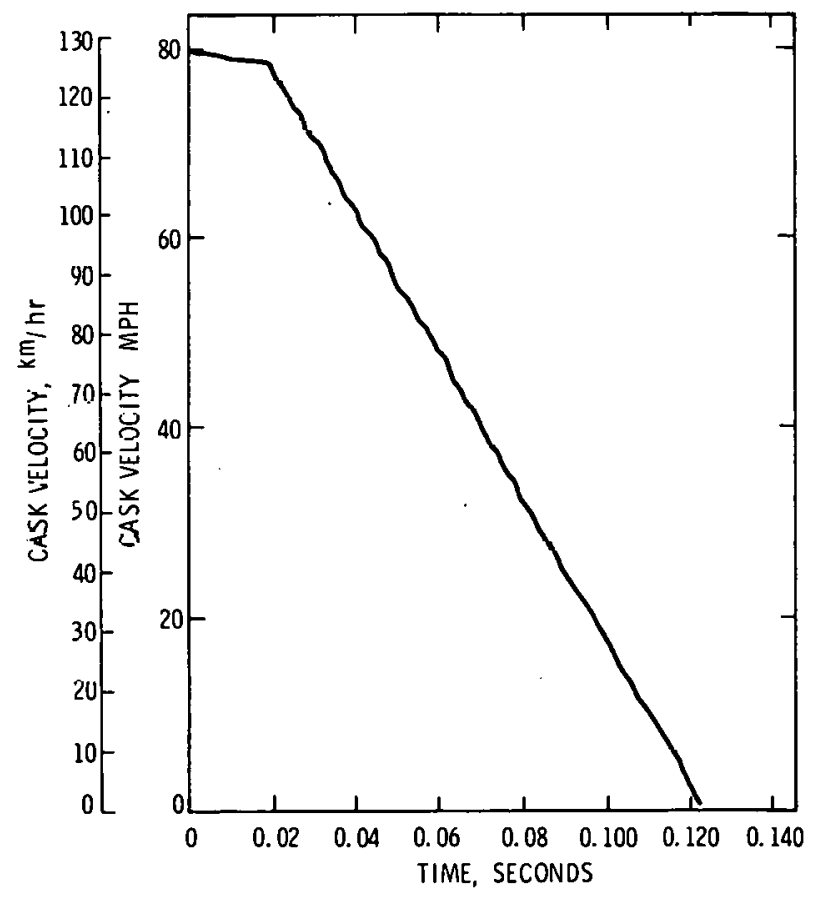

Figure 13. Velocity-Time History for the Rail Cask After Impact 


\section{Finite Element Models}

In order to understand better the generic behavior of casks subjected to severe impacts, some finite element modeling is being performed. To date, a side impact was analyzed with the HONDO 3 Program. (HONDO is a dynamic finite-element program which models large deformations in two-dimensional or axisymmetric solids.) For the problem of a side impact, the code was modified to restrain node movement past a plane. The cask body was assumed to be in a state of plane strain and was given an initial velocity equal to the impact velocity.

Figure 14 illustrates the mesh for a model cask. The cask cross section, including the outer and inner shells and the lead shielding, is modeled.

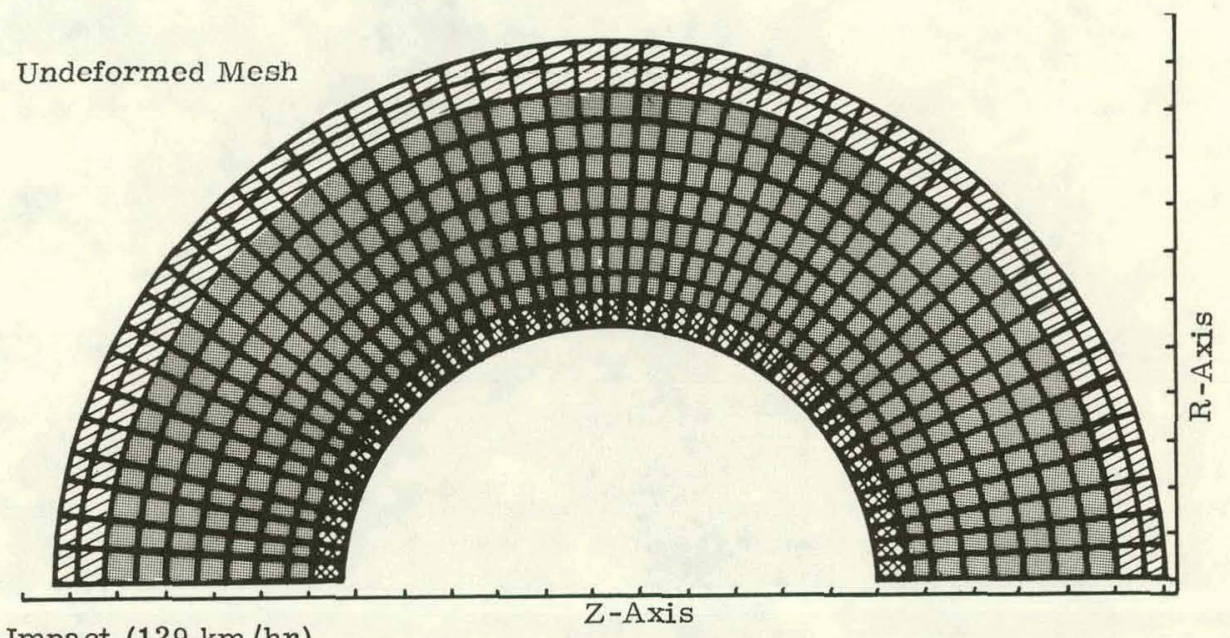

Cask Model $80 \mathrm{mph}$ Impact $(129 \mathrm{~km} / \mathrm{hr})$

Figure 14. Undeformed Cask Mesh for the HONDO Code

Figure 15 illustrates the deformed mesh after a $129 \mathrm{~km} / \mathrm{hr}(80 \mathrm{mph})$ impact. As can be seen, the cask is severely deformed.

Time:

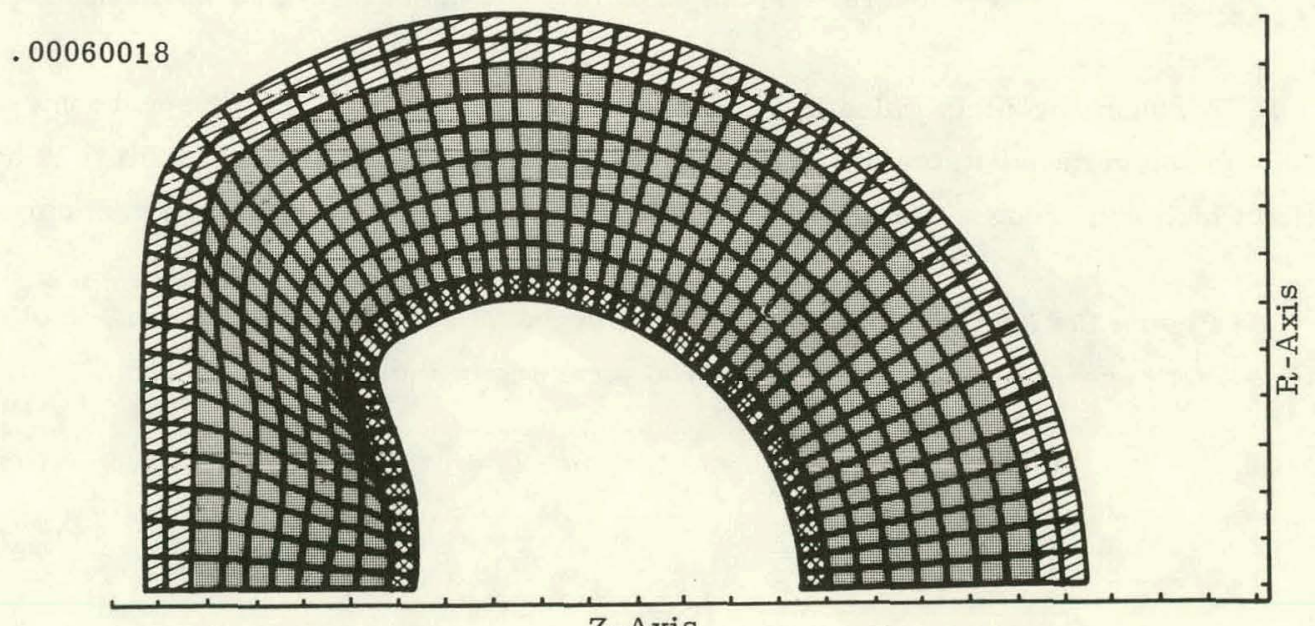

Cask Model $80 \mathrm{mph}$ Impact $(129 \mathrm{~km} / \mathrm{hr})$

Figure 15. Deformed Mesh for the Cask Calculated with IIONDO 
Figure 16 illustrates the scale model cross section after impact into a steel target at a centrifuge facility. As shown in the photograph, there is good qualitative agreement. It is important to observe that there is very little separation of the lead from the shells. This is important in veiw of the fact that this computer model does not have provisions for a sliding interface or separation of materials.

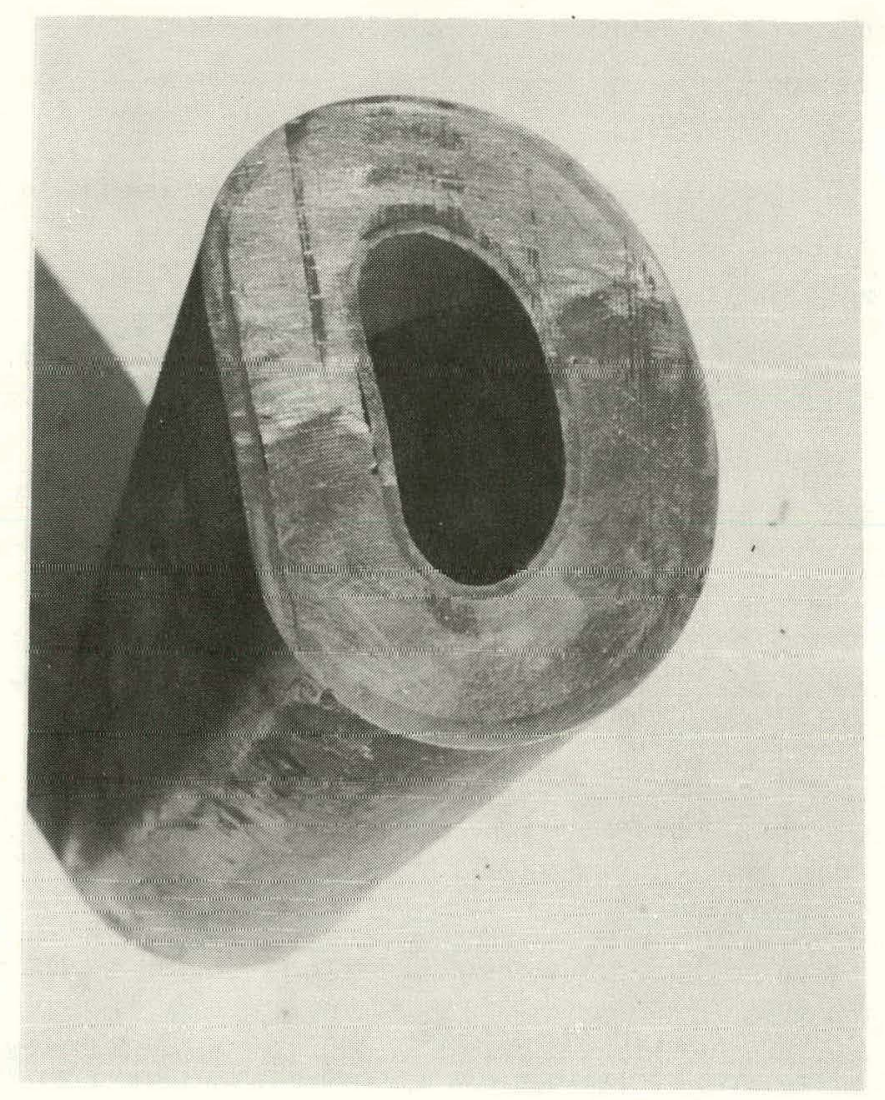

Figure 16. Photograph of Scale-Model Cask Cross Section

A second problem which is being investigated analytically is the severe end-on impact. This problem necessitates the use of a code with a sliding interface capability to handle lead motion which can occur within the shells. This is commonly known as lead slumping.

Figure 17 illustrates the impact end of a model cask tested at $129 \mathrm{~km} / \mathrm{hr}(80 \mathrm{mph})$. As can be seen, there was significant bulging and straining of the outer shell. 


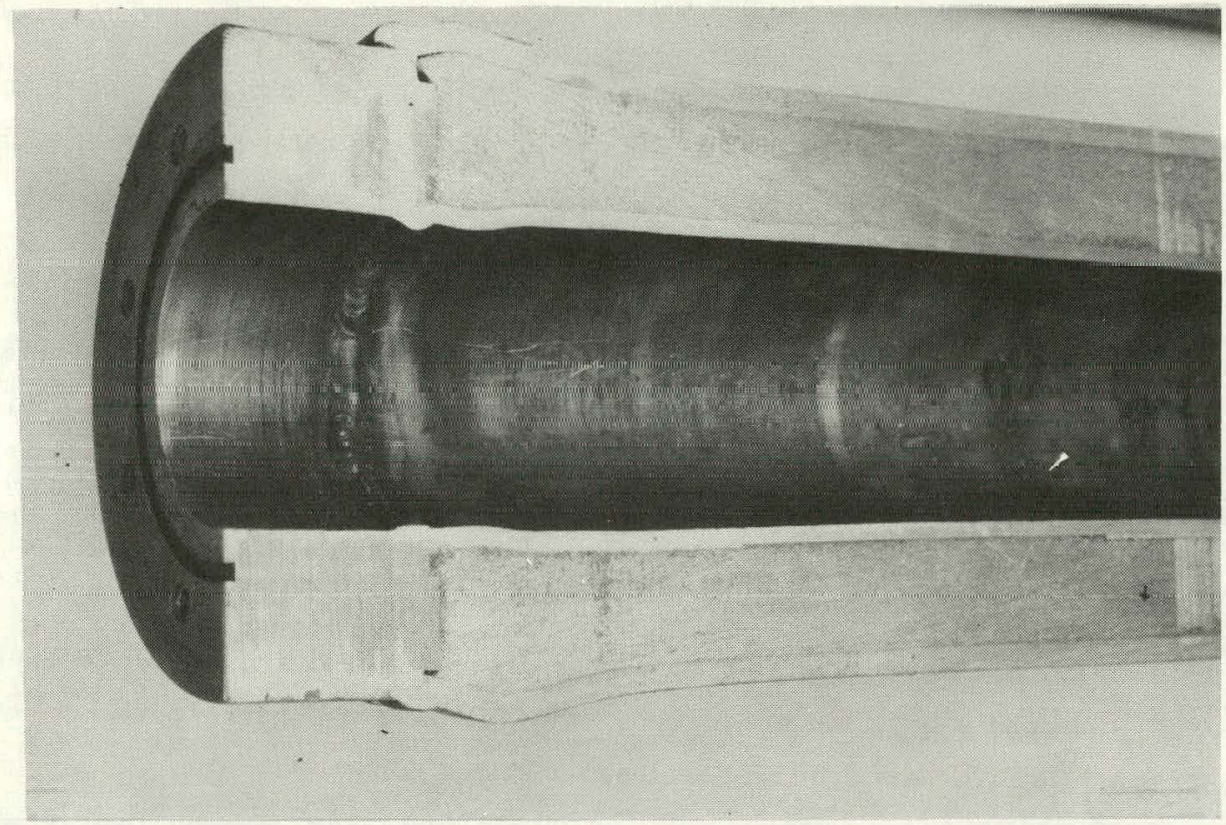

Figure 17. Impacted End of a Cask Model Tested at $129 \mathrm{~km} / \mathrm{hr}(80 \mathrm{mph})$

Figure 18 illustrates the opposite end of the cask. Here lead slumping resulted in a gap in the shielding. The same HONDO code used to model the side impact was modified to handle a sliding interface in this impact configuration. The end impact problem will be treated as a axisymmetric axial impact with friction between the lead shielding material and the steel shells.

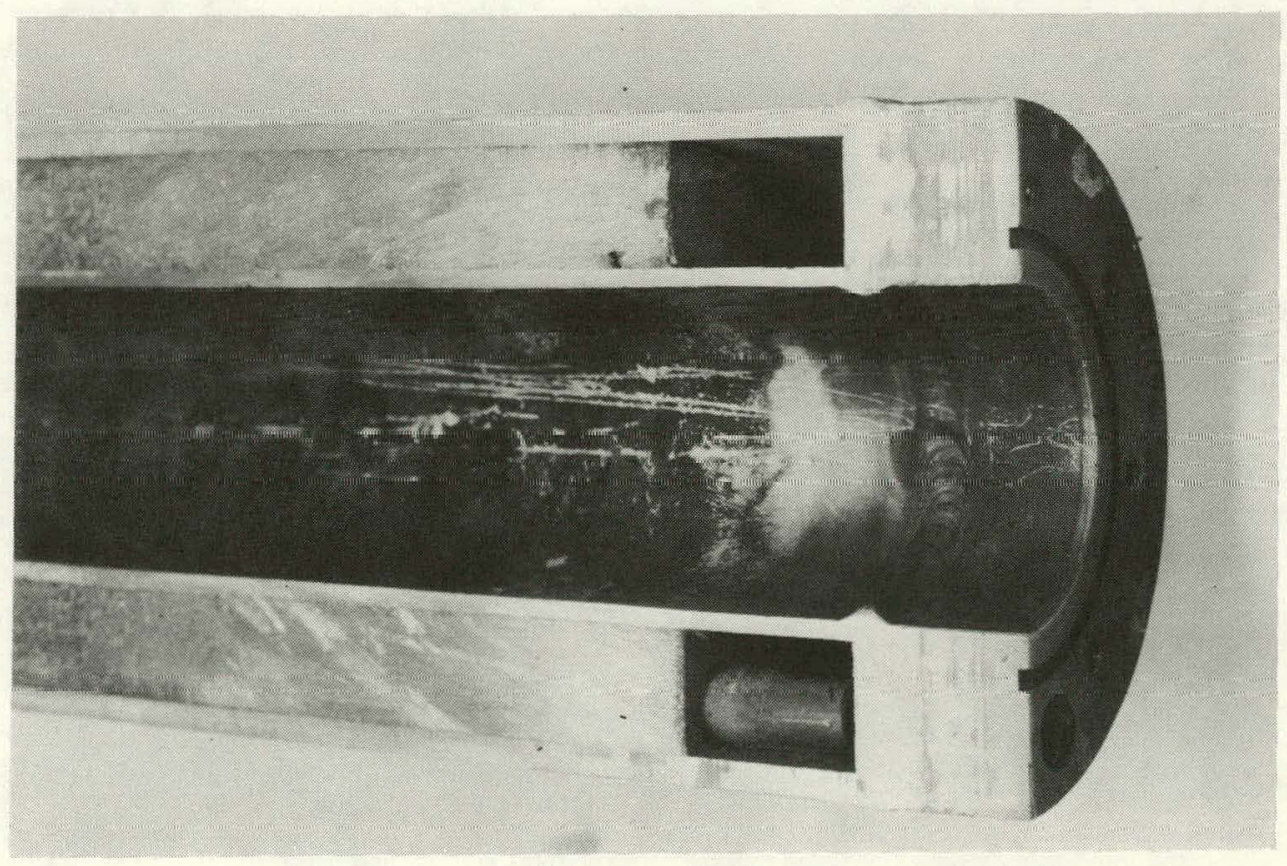

Figure 18. Cross Section of a Model Cask Subjected to an End Impact 


\section{Conclusion}

Some of the scale modeling and analytical techniques being employed in analyses relating to spent nuclear fuel shipping casks subjected to severe accident environments have been described and some results presented. The results of the scale model tests agree well with the analytical predictions.

The scale model studies have included models of vehicular structures, impact targets, and shipping casks. In addition to testing model casks in simulated accident conditions involving vehicles, model casks were impacted into unyielding targets at high velocities. These models were sectioned to reveal information regarding deformation modes and lead movement within the structure.

Analytically, the transportation systems and casks were analyzed with the SHOCK computer code. This mathematical analysis was used to predict the influence of the transportation system and the rigid body dynamics of the cask in an accident situation. From this lype of analysis, an estimate of the severity of a possible final cask impact into a hard target was obtained. Detailed deformation information of the cask in such an impact was obtained from a follow up model using the HONDO code. The HONDO code handled a side and end impact into an unyielding target. Comparison of results from a side impact analysis compared well with scale model results.

\section{References}

1. Gabrielson, V. K., and Reese, R. T., "SHOCK Code User's Manual, A Computer Code to Solve the Dynamic Response of Lumped - Mass Systems," SCL-DR-69-98, Sandia Laboratories, Livermore, CA (1969).

2. Dennis, A. W. "Analytical Investigation ol a Grade-C'rossing Accidenl Bulween a Railroad Train and a Spent Reactor Fuel Cask", SAND74-0317, Sandia Laboratories, Albuquerque, NIM (January 1975).

3. Key, S. W., "HONDO, a Finite Element Computer Program for the Large Deformation Dynamic Response of Axisymmetric Solids," SLA-74-0039, Sandia Laboratories, Albuquerque, NM (January 1974). 
DISTRIBUTION:

TID-4500-R66 UC-71 (163)

Battelle-Pacific Northwest Laboratory P. O. Box 999

Richland, WA 99352

Attn: B. Andrews

U.S. Department of Energy

3833 Altez, NE

Albuquerque, NM 87111

Attn: K. Archibeque

Bales Equipment Corporation

P.O. Drawer $Z$

4100 National Parks Highway

Carlsbad, NM 88220

Attn: Wilson Bales, Jr., President

Transportation Safety Institute

Hazardous Materials

6500 South MacArthur Blvd

Oklahoma City, OK 73125

Attn: A. C. Bensmiller, Program Mgr.

Nuclear Assurance Corporation

24 Executive Park West

Atlanta, GA 30329

Attn: R. E. Best, Mgr., Engineering Services

Yankee Atomic Electric Company

20 Turnpike Road

Route 9

Westboro, MA 01581

Attn: J. M Bucheit, Engineer

Bureau of Motor Carrier Safety

U.S. Department of Transporation

P.O. Box 9253

Albuquerque, NIM 87119

Attn: E. F. Calt, Safety Investigator

Stearns-Roger, Inc.

P. O. Box 5888

Denver, CO 80217

Attn: R.W. Cecil

U.S. Department of Energy (2)

Albuquerque Operations Office

P.O. Box 5400

Albuquerque, NM 87115.

Attn: J. N. Cook

W. C. Purchase

Consumers Power Company

1945 Parnall Road

Jackson, MI 49201

Attn: M. Dickson
Tennessee Valley Authority

630 Commerce Union Bank Building

Chattanooga, TN 37401

Attn: C. Fry, Traffic Branch Division of Purchasing

Office of Environmental Studies

Research and Test Department

American Railroads Building

1920 L Street NW

Washington, DC 20036

Attn: C.P. Furber, Manager

Atomic Industrial Forum, Inc.

7101 Wisconsin Avenue

Washington, DC 20014

Attn: E. Gordon, Nuclear Fuel Cycle, Project Manager

J. S. Glynn, Regional Supervisor

Bureau of Railroad Safety

Department of Transportation

Federal Railroad Administration

Federal Building, Rm $11 \mathrm{~A} 23$

519 Taylor Street

Ft. Worth, TX 76102

C. F. Hanley

Nuclear Fuel Transportation Manager

Irradiated Fuel Transport System

Boeing Engineering and Construction

a Division of the Boeing Company

P. $\cap$. Rox 3707

Seattle, WA 98124

Barnwell Operations

Nuclear Division/NL Industries, Inc.

P. O. Box 928

Barnwell, SC 29812

Attn: A. A. Haskell, Jr., Mgr., Tcch. Scrvioee

Missouri Pacific Railroad Company

210 North 13 th Street

St. Louis, MO 63102

Attn: M. F. Hengel, Mechanical Engineer

Exxon Nuclear Company, Inc.

Tuel Dcsign and Enginoering

2101 Horn Rapids Road

Richland, WA 93352

Attn: R. G. Hill, Sr. Engineer 
D. B. Henks, Jr.

Asst. to Supt. of Transportation

Atchison, Topeka \& Santa Fe Railway Co. 80 East Jackson Blvd.

Chicago, IL 60604

General Electric Company

Fuel Recovery Operation

Nuclear Energy Division

175 Curtner Avenue

San Jose, CA 95125

Attn: R. H. Jones, Manager

Transportation Systems

Lovelace ITRI

Box 5890

Albuquerque, NM 87115

Attn: C. P. J. Kelley

New Mexico Motor Carricrs' $\Lambda$ ssoc., Inc. P.O. Box 25266

Albuquerque, NM 87125

Attn: J. O. Larson, Managing Directór

M. Lauriente, F. E.

Office of the Secretary

Office of Systems Engineering

Department of Transportation

4007 th Street, SW

Washington, DC 20590

Batellc-Columbus Laboratories

50.5 King Avenue

Columbus, OH 43201

Attn: E. C. Lusk

Federal Highway Administration

New Mexico Division

1') US C'ourthouse

Santa Fe. NM 87501

Attn: J. F. MacAllister, Division Engineer

L. Macklin, President

Transnuclear, Inc.

One North Broadway

White Plains, NY 10601

General Atomic Company

Fort St. Vrain Fuel Project

P. O, Box 81608

San Diego, CA 92138

Attn: R. L, Moore

Exxon Nuclear Company, Inc.

Advanced Storage and Transportation

Pruject Engineering

Fuel Reprocessing Department

777-106th Avenue Northeast, C-00777

Bellevue, WA 98009

Attn: J. H. Nordahl, Manager
J. R. Paschall

Assistant General Attorney Law Dept.

Chesapeake \& Ohio Railway

1700 Terminal Tower

P.O. Box 6419

Cleveland. $\mathrm{OH} 44101$

Allied-General Nuclear Services

P.O. Box 847

Barnwell, SC 29812

Attn: R. W. Peterson

Director of Transportation

G. M. Randall, Safety Inspector

Bureau of Railroad Safety

Department of Transportation

Federal Railroad Administration

Room 11-A-23, Federal Building

819 Taylor Street

Fort Worth, TX 76102

Consolidated Edison Company of NY, Inc.

4 Irving Place

New York, NY 10003

Attn: J. A. Pezzello, Sr. Fuel Engineer

The SM Stoller Corporation

Suite 800 , Colorado Building

Boulder, CO 80302

Attn: M. H. Raudenbush

Union Pacific Railroad

1416 Mnige Strept

Omaha, NE 68179

Attn: P. E. Rhine, Engr, of Tests

J. L. Kidihalgh, President

Kidihalgh \& Associates

Nuclear and Thermal

Energy Systems Consultants

2112 Iuka Avenue

Columbus, OH 43201

Western Interstate Nuclear Board

P. O. Box 15038

Lakewood, CO 80215

Attn: W. M. Kogers, Jr., Director

Oak Ridge National Lab

P. O. Bor X

Oak Ridge, TN 37830

Attn: D. Seagren

Flectric Power Research Institute

3142 Hillview Avenue

P.O. Bux 10412

Palo Alto, CA 94304

Attn: G. Sliter, Project Mgr. 
B. R. Teer, Vice President

Transnuclear, Inc.

One North Broadway

White Plains, NY 10601

K. J. Vieg

Director of Transportation Safety

Illinois Department of Transportation

2300 South Dirksen Parkway

Springfield, IL 62764

Westinghouse Electric Corporation

Nuclear Service Division

Power Systems

P.O. Box 2728

Pittsburgh, PA 15230

Attn: H. E. Walchli, Advisory Engineer

J. W. White, PE

Regional Administrator

U. S. Department of Transporation

Federal Highway Administration

819 Taylor Street

Ft. Worth, TX 76102

I. Yabe, Manager

Nuclear Safety Research Association

Room 1037, National Press Building

Corner 14 th and $F$ Street, NW

Washington, DC 20004

Dr. Y. Sousselier

Commissariat a 1'Energie Atomique

Commission de Surete des Transports

BP No. 6, F-92260

Fontenay-aux-Roses, Paris, France

Dipl. Ing. Schulz-Forberg

Bundesanstalt fur Materialpruefung (BAM)

Unter den Eichen 87

D- 1000 Berlin 45

Federal Republic of Germany

Gerald E. Swindell

International Atomic Energy Agency

Radiological Safety Section

Karntner Ring 11, P. O. Box 580

A-1011, Vienra, Austria

D. G. Walker

Counselor (Atomir. Finergy)

Australian Embassy

Washington. DC

J. Gaunt

Rritish Embassy

3100 Massachusetts Avenue

Washington, DC 20008

Mr. Tetsuo Goto

Nuclear Industry Development

Japan Atomic Industrial Forum. Inc.

No. 1-13, 1-Chome, Shimbashi, Minato-ku, Tokyo, Japan

Stanley Williamson

British Nuclear Fuels Limited

Risley, Warrington, WA 3 6AS,

Cheshire, England

5000

5100
A. Narath

J. K. Galt

E. H. Beckner

A. W. Snyder

D. J. McCloskey

J. V. Walker

R. M. Jefferson (50)

W. A. Von Riesemann

R. E. Luna

R. B. Pope

G. C. Allen

J. A. Andersen

J. M. Freedman

S. H. Sutherland

H. R. Yoshimura (100)

J. H. Scott

R. S. Claassen

E. A. Aas

T. L. Werner (5)

W. L. Garner (3)

For DOE/TIC (Unlimited Release) 